\title{
Regulation of Renal Blood Flow by Plasma Chloride
}

\author{
Christopher S. Wilcox, Department of Medicine and Clinical Pharmacology, \\ Harvard Medical School, The Brigham and Women's Hospital, \\ Boston, Massachusetts 02115
}

A B S T R A C T Micropuncture studies have shown that glomerular filtration rate (GFR) falls in response to a rise in $\mathrm{Na}^{+}$or $\mathrm{Cl}^{-}$concentrations in the loop of Henle, whereas studies in isolated kidneys have shown that GFR falls in response to osmotic diuresis. To define the separate effects of an acute increase in plasma sodium $\left(\mathrm{P}_{\mathrm{Na}}\right)$, chloride $\left(\mathrm{P}_{\mathrm{Cl}}\right)$ or osmolality $\left(\mathrm{P}_{\text {osmol }}\right)$, changes in renal blood flow (RBF) and GFR were measured during intrarenal infusions of hypertonic $\mathrm{NaCl}$, $\mathrm{NaHCO}_{3}, \mathrm{Na}$ acetate, dextrose, $\mathrm{NH}_{4} \mathrm{Cl}$ or $\mathrm{NH}_{4}$ acetate to denervated kidneys. The infusions raised $\mathrm{P}_{\text {osmol }}$ at the experimental kidney by 30-45 mosmol. RBF increased abruptly by $10-30 \%$ with all hypertonic infusions indicating that an acute increase in plasma tonicity causes renal vasodilatation. Renal vasodilatation persisted or increased further during infusion of dextrose, $\mathrm{NaHCO}_{3}$ and $\mathrm{Na}$ acetate, but GFR was unchanged. In contrast, during infusion of the two Clcontaining solutions, vasodilatation was reversed after 1-5 min and RBF and GFR decreased $(P<0.01)$ below preinfusion levels. Prior salt depletion doubled the vasoconstriction seen with hypertonic $\mathrm{NaCl}$ infusions. Overall, changes in RBF were unrelated to changes in $\mathrm{P}_{\mathrm{Na}}$ or fractional $\mathrm{Na}$ or fluid reabsorption but correlated with changes in $\mathrm{P}_{\mathrm{Cl}}(r=-0.91)$ and fractional $\mathrm{Cl}^{-}$reabsorption $(r=0.94)$. The intrafemoral arterial infusion of the two Cl-containing solutions did not increase femoral vascular resistance. In conclusion, hyperchloremia produces a progressive renal vasoconstriction and fall in GFR that is independent of the renal nerves, is potentiated by prior salt depletion and is related to tubular $\mathrm{Cl}^{-}$reabsorption. Chloride-induced vasoconstriction appears specific for the renal vessels.

\section{INTRODUCTION}

The maintenance of fluid and electrolyte balance by the kidney is achieved by integrated adjustments in glomerular filtration and tubular reabsorption. When

Received for publication 21 July 1982 and in revised form 24 November 1982. the adequacy of the extracellular volume $(\mathrm{ECV})^{1}$ is threatened by salt depletion, impaired proximal tubule reabsorption or a high perfusion pressure, renal vasoconstriction restricts the volume of filtrate delivered to the tubules (1-5). A mechanism that can relate glomerular filtration to distal fluid delivery has been identified in micropuncture experiments in which single nephron glomerular filtration rate (SNGFR) has been found to fall during a selective increase in the $\mathrm{Na}^{+}$or $\mathrm{Cl}^{-}$concentrations or osmolality of early distal tubule fluid (6-8).

In previous experiments, we (9) and others $(10,11)$ showed that intrarenal infusion of hypertonic $\mathrm{NaCl}$ solution causes transient vasodilatation followed by sustained vasoconstriction. Schnermann et al. (8) demonstrated that retrograde injection of $\mathrm{Cl}$-containing solutions into the distal tubule regularly elicited a decrease in SNGFR, whereas similar injections of $\mathrm{Na}$ containing solutions did not. In contrast, in experiments on the isolated kidney, Nizet (12-14) concluded that there was no specific effect of increased $\mathrm{Na}^{+}$or $\mathrm{Cl}^{-}$concentration on renal vascular resistance but that the GFR varied in direct proportion to tubular fluid reabsorption. To settle these differences between the responses of the isolated kidney and the nephron perfused retrogradely, changes in renal vascular resistance of the intact kidney occurring in response to an acute increase in plasma sodium $\left(\mathrm{P}_{\mathrm{Na}}\right)$, chloride $\left(\mathrm{P}_{\mathrm{CI}}\right)$, or osmolality $\left(\mathrm{P}_{\text {osmol }}\right)$ were investigated.

\section{METHODS}

\section{Preparation}

Experiments were performed on 48 male greyhounds weighing $28 \pm 2 \mathrm{~kg}$ (mean \pm SEM) and fed a diet of meat and dog biscuits; food and water were withheld for $12 \mathrm{~h}$ before experiments.

\footnotetext{
'Abbreviations used in this paper: ECV, extracellular volume; FBF, femoral blood flow; FF, filtration fraction; GFR, glomerular filtration rate; Hct, hematocrit; MAP, mean arterial pressure; PS, plasma solid; $R / F$, fractional reabsorption; RPF, renal plasma flow; $R B F$, renal blood flow; SNGFR, single nephron glomerular filtration rate.
} 
Dogs were anesthetized with intravenous pentobarbitol and were ventilated mechanically (arterial blood $\mathrm{pCO}_{2}, 32-$ $42 \mathrm{mmHg}$ ). Mean arterial blood pressure (MAP) was recorded via a cannula in a femoral artery (as the damped electrical output from a pressure transducer [Statham Instruments, Inc., Oxnard, CA]).

The "experimental" kidney was denervated by autotransplantation to the neck of the same dog by anastomosis to the carotid artery and jugular vein as described previously (15, 16). The artery to the experimental kidney was encircled by an electromagnetic flow probe connected to a pulsed-logic blood flow meter (Biotronex Laboratory, Inc., Kensington, MD). About 1 in. distal to the flow probe, the artery was cannulated with an 18-gauge needle to infuse solution I (see below). A tributary of the jugular vein was cannulated to obtain samples of renal venous blood. The ureter was cannulated and urine flow rate was displayed graphically by a drop counter (Devices Ltd., London, England) and its volume measured gravimetrically. The experimental kidney was placed in a box filled with light liquid paraffin mineral oil and maintained at $37^{\circ} \mathrm{C}$ by a water jacket. The ureter of the contralateral kidney was cannulated, but this kidney was otherwise undisturbed.

Through a cannula inserted into a brachial vein, a solution of two-thirds $0.154 \mathrm{M} \mathrm{NaCl}$ solution and one-third $1.10 \mathrm{M}$ mannitol was infused at a rate of $0.04 \mathrm{ml} \mathrm{min}^{-1} \mathrm{~kg}$ body $\mathrm{wt}^{-1}$ (solution 2). The markers used to estimate GFR and renal plasma flow rate (RPF) were added to this infusion. During surgery, the animals received $500 \mathrm{ml}$ of isooncotic $\left(6 \mathrm{~g}^{\left.100 \mathrm{ml}^{-1}\right)}\right.$, dextran (average molecular weight 110,000$)$ in $0.154 \mathrm{M} \mathrm{NaCl}$ solution (Dextraven 110, Fisons, Ltd., London, England). Infusion I (intrarenal) was delivered at 0.1 $\mathrm{ml} \mathrm{m^{-1 }}$ body wt $\mathrm{kg}^{-1}$. It was initially $0.154 \mathrm{M} \mathrm{NaCl}$ solution. $1 \mathrm{~h}$ after completing surgery, urine was collected from each kidney for a 15-min collection period and blood samples (10-15 ml) were drawn from the femoral artery and the renal vein at the midpoint. Dextraven 110 was infused to replace blood losses.

\section{Experimental protocol}

Effects of hypertonic intrarenal infusions on renal function. The infusion into the artery of the experimental kidney was changed from $0.154 \mathrm{M} \mathrm{NaCl}$ to either $\mathrm{NaCl}$, $\mathrm{NaHCO}_{3}, \mathrm{Na}$ acetate, $\mathrm{NH}_{4} \mathrm{Cl} \mathrm{NH}_{4}$ acetate or dextrose at $1.232 \mathrm{M}$ for $30 \mathrm{~min}$, but the rate of infusion was not changed. Urine was collected for the last 15 min during which blood samples were drawn. Thereafter, the infusion was returned to $0.154 \mathrm{M} \mathrm{NaCl}$ solution for a further $30 \mathrm{~min}$ and urine was collected for the last $15 \mathrm{~min}$ with a blood sample at the midpoint.

Effects of prior salt depletion on renal hemodynamics during hypertonic $\mathrm{NaCl}$ infusion. In five experiments, the dogs received furosemide $\left(80 \mathrm{mg} \mathrm{d} \mathrm{d}^{-1}\right.$ with the food) for 2 $\mathrm{d}$ to cause ECV depletion. The second dose was given $18 \mathrm{~h}$ before study and no further food or fluid was given. These dogs received the intrarenal infusions of hypertonic $\mathrm{NaCl}$ according to the protocol described above.

Effects of intraarterial infusions of hypertonic solutions on femoral blood flow. In four dogs, the hypertonic solutions used in protocol A were infused into a femoral artery at $0.1 \mathrm{ml} \mathrm{min} \mathrm{mg}^{-1} \mathrm{~kg}$ body $\mathrm{wt}^{-1}$. These infusions were given for $\sim 15$ min with $0.154 \mathrm{M} \mathrm{NaCl}$ infused for 15 min between each one. Femoral blood flow (FBF) was assessed by a noncannulating blood flow meter placed around the femoral artery at least $1 \mathrm{in}$. proximal to the site of the infusion.

\section{Laboratory methods}

Details of the analytical methods have been described previously (16). Measurements of $\mathrm{Na}^{+}$and $\mathrm{K}^{+}$concentrations were made with an EEL flame photometer, $\mathrm{Cl}$ with a Corning chloride meter (Corning Medical, Corning Glass Works, Corning, NY), osmol with an Advanced osmometer (Advanced Instruments, Inc., Needham Heights, MA), $\mathbf{p H}, \mathbf{p C O}_{2}$ and $\mathrm{pO}_{2}$ of arterial and renal venous blood with a Radiometer blood gas analyzer (Radiometer Co., Copenhagen, Denmark) and plasma $\mathrm{HCO}_{3}$ calculated from a standard normogram (Siggaard-Andersen). Hematocrit (Hct) was estimated as the mean of two measurements with a microhematocrit centrifuge. Plasma solid concentration (PS; indicating plasma protein concentration) was estimated by dessicating a weighed quantity of plasma to constant weight and reweighing with correction for the measured content of ions. The radioactivity of arterial and renal venous plasma and urine were counted with a Packard autogamma counter (Packard Instruments, Inc., Downers Grove, IL).

Calculation of results. The RPF was calculated as the clearance of Hippuran corrected for renal extraction. The renal blood flow (RBF) was calculated from RPF and Hct. The electromagnetic flow meter was used to record the time course of any changes in RBF. The GFR was calculated as the clearance of EDTA and the filtration fraction (FF) calculated as GFR/RPF. Paired comparisons were used and values of $2 P<0.05$ were taken as statistically significant.

\section{RESULTS}

Blood pressure and composition before and during hypertonic infusions. Table I details the initial values of MAP and blood composition at the experimental kidney and the changes produced by the hypertonic infusions. Since there were no differences in initial values between groups, the mean starting values were pooled. The MAP was not altered during any infusion. The $\mathrm{P}_{\text {osmol }}$ at the experimental kidney was increased $\sim 30-45$ mosmol. Infusions containing $\mathrm{Na}^{+}$or $\mathrm{Cl}^{-}$increased $\mathrm{P}_{\mathrm{Na}}$ or $\mathrm{P}_{\mathrm{Cl}} \sim 20-25 \mathrm{mM}$. Infusion of $\mathrm{NaCl}$, dextrose and especially $\mathrm{NH}_{4} \mathrm{Cl}$ produced a systemic metabolic acidosis; infusions of $\mathrm{NaHCO}_{3}$, and $\mathrm{Na}$ acetate produced a systemic metabolic alkalosis. However, there were no differences between the $\mathrm{pH}$ in the renal vein and the systemic circulation except during intrarenal infusion of $\mathrm{NaHCO}_{3}$. The systemic plasma hydrogen ion concentration $\left(\mathrm{P}_{\mathrm{H}}\right)$ was higher during the infusion of $\mathrm{NH}_{4}$-containing solutions than during the corresponding $\mathrm{Na}$-containing solutions.

Steady-state changes in RBF, GFR and renal clearance during intrarenal hypertonic infusions. The renal function of the experimental kidney during the initial infusion of $0.154 \mathrm{M} \mathrm{NaCl}$ and the relationship of its function to that of the control kidney were strictly comparable to that reported previously (16). There were no differences between the RBF, RPF, or fractional excretion of sodium $\left(\mathrm{FE}_{\mathrm{Na}}\right)$ or chloride $\left(\mathrm{FE}_{\mathrm{Cl}}\right)$ between the experimental and control kidneys, 
TABLE I

Blood Pressure and Composition

\begin{tabular}{|c|c|c|c|c|c|c|c|}
\hline & \multirow[b]{2}{*}{$\begin{array}{l}\text { Starting value } \\
\qquad(n=48)\end{array}$} & \multicolumn{6}{|c|}{ Change during infusion of $1.232 \mathrm{M}$ solution } \\
\hline & & $\begin{array}{c}\mathrm{NaCl} \\
(n=17)\end{array}$ & $\begin{array}{l}\mathrm{NH}_{4} \mathrm{Cl} \\
(n=6)\end{array}$ & 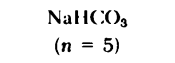 & $\begin{array}{l}\text { Na Acetate } \\
(n=6)\end{array}$ & $\begin{array}{l}\text { Dextrose } \\
(n=9)\end{array}$ & $\begin{array}{c}\mathrm{NH}_{4} \text { Acetate } \\
(n=5)\end{array}$ \\
\hline $\mathrm{MAP}, m m H g$ & $164 \pm 22$ & $-3 \pm 15$ & $+8 \pm 15$ & $-3 \pm 7$ & $-8 \pm 12$ & $-1 \pm 4$ & $-4 \pm 7$ \\
\hline $\mathrm{P}_{\text {intmol }}$, mosmol $\mathrm{kg}^{-1}$ & $310.2 \pm 11.0$ & $+41.6 \pm 13.7^{\circ}$ & $+45.5 \pm 16.9^{\circ}$ & $+39.0 \pm 12.7^{\circ}$ & $+33.7 \pm 7.9^{\circ}$ & $+30.3 \pm 12.2^{\circ}$ & $+37.6 \pm 7.5^{\circ}$ \\
\hline $\mathrm{P}_{\mathrm{N} .1}, \mathrm{mmol} \mathrm{l}^{-1}$ & $147.4 \pm 5.8$ & $+22.4 \pm 7.4^{\circ}$ & $-1.0 \pm 0.9$ & $+21.0 \pm 4.2^{\circ}$ & $+18.5 \pm 2.3^{\circ}$ & $-6.2 \pm 1.7^{\circ}$ & $-0.8 \pm 1.3$ \\
\hline $\mathrm{P}_{\mathrm{K}}, \mathrm{mmol} \mathrm{l}^{-1}$ & $3.64 \pm 0.54$ & $-0.3 \pm 0.3^{\circ}$ & $+1.0 \pm 0.3^{\circ}$ & $-0.3 \pm 0.2 \downarrow$ & $-0.9 \pm 0.6 \rrbracket$ & $-0.2 \pm 0.2 \ddagger$ & $+0.6 \pm 0.1^{\circ}$ \\
\hline $\mathrm{P}_{\mathrm{cl}}, \mathrm{mmol} \mathrm{l}^{-1}$ & $110.4 \pm 15.5$ & $+22.2 \pm 5.4^{\circ}$ & $+27.8 \pm 7.1^{\circ}$ & $-4.4 \pm 1.1^{\circ}$ & $-4.7 \pm 2.7 \S$ & $-6.0 \pm 2.7^{\circ}$ & $-6.6 \pm 3.3 \ddagger$ \\
\hline $\mathrm{P}_{11}$, nmol l $^{-1}$ & $47.6 \pm 1.8$ & $+4.8 \pm 4.7^{\circ}$ & $+17.6 \pm 7.0^{\circ}$ & $-16.0 \pm 4.3^{\circ}$ & $-7.8 \pm 6.3 \ddagger$ & $+4.3 \pm 1.7^{\circ}$ & $+0.5 \pm 4.2$ \\
\hline $\mathrm{p}_{\left(\mathrm{CO}_{2}\right.}, \mathrm{mmHg}$ & $36.7 \pm 8.9$ & $+1.2 \pm 4.0$ & $+0.3 \pm 8.5$ & $+4.5 \pm 2.1$ & $+0.8 \pm 6.5$ & $-0.5 \pm 4.4$ & $-1.5 \pm 6.6$ \\
\hline $\mathrm{P}_{\mathrm{O}_{2}}, \mathrm{mmHg}$ & $83.1 \pm 15.2$ & $+1.5 \pm 5.1$ & $+4.3 \pm 9.8$ & $+0.5 \pm 5.0$ & $+5.0 \pm 6.6$ & $-1.3 \pm 4.4$ & $+1.0 \pm 2.6$ \\
\hline $\mathrm{P}_{1 \mathrm{HC} \mathrm{C}_{3}}, \mathrm{mmol} \mathrm{l}^{-1}$ & $18.9 \pm 0.8$ & $-2.4 \pm 2.3^{\circ}$ & $-5.2 \pm 2.7^{\circ}$ & $+8.1 \pm 0.6^{\circ}$ & $+3.2 \pm 2.8 \rrbracket$ & $-2.2+1.2^{\circ}$ & $-1.9 \pm 1.1 t$ \\
\hline PS, $g 100 g^{-1}$ & $5.74 \pm 0.72$ & $-0.53 \pm 0.39^{\circ}$ & $+0.06 \pm 0.08$ & $-0.28 \pm 0.20 \ddagger$ & $-0.29 \pm 0.27 \ddagger$ & $-0.08 \pm 0.14$ & $+0.21 \pm 0.22$ \\
\hline Het, \% & $48.9 \pm 7.7$ & $-4.1 \pm 3.1^{\circ}$ & $+1.8 \pm 1.8$ & $-1.6 \pm 0.9 \rrbracket$ & $-0.2 \pm 3.7$ & $-3.7 \pm 1.5^{\circ}$ & $+4.2 \pm 2.5 \ddagger$ \\
\hline
\end{tabular}

Column 1 shows the mean $( \pm S D)$ initial value for the entire group $(n=48)$ and subsequent columns show the mean $( \pm S D)$ absolute changes produced in the blood perfusing the experimental kidney 15-30 min after starting intrarenal arterial infusions.

${ }^{\circ} P<0.001$. $\ P<0.05 ; \S P<0.01$;

but the GFR and FF were slightly lower (average, 7\%; $P<0.01)$ at the experimental kidney.

The changes in renal hemodynamics $15-30 \mathrm{~min}$ after starting infusions of the four hypertonic solutions that did not contain $\mathrm{Cl}^{-}$are shown in Table II. There were significant increases in RBF and RPF for all save $\mathrm{NH}_{4}$ acetate. There were no significant changes in GFR and FF decreased with each infusion. All these changes in RBF and RPF were reversible, except that there was a persistent fall in FF after the infusion of the two acetate-containing solutions. Thus, hypertonic infusions that did not contain $\mathrm{Cl}^{-}$or $\mathrm{NH}_{4}^{+}$led to reversible renal vasodilatation. The changes in renal hemodynamics that occurred after 15-30 min of infusion of hypertonic solutions containing $\mathrm{Cl}^{-}$were quite different (Table II). RBF, RPF, and GFR were all reduced significantly and these changes were greater during the infusion of $\mathrm{NH}_{4} \mathrm{Cl}$ than $\mathrm{NaCl}(P<0.05)$. The FF was maintained during infusion of $\mathrm{NaCl}$, but it fell during $\mathrm{NH}_{4} \mathrm{Cl}$. These changes (except for the fall in GFR with $\mathrm{NH}_{4} \mathrm{Cl}$ ) had reversed within 15-30 min after stopping the infusions. Thus, hypertonic $\mathrm{Cl}^{-}$ infusions produced renal vasoconstriction and a fall in GFR that was more pronounced when $\mathrm{NH}_{4}{ }^{+}$was the cation.

In Fig. 1 are shown the percentage changes in $\mathrm{RBF}$ of the experimental kidney alone and relative to the control kidney during the different infusions. During the infusion of $\mathrm{Na}$ acetate, dextrose, and $\mathrm{NaHCO}_{3}$, $\mathrm{RBF}$ increased, whereas during the infusion of the two Cl-containing solutions, it decreased. These changes in $\mathrm{RBF}$ were also seen when the RBF of the experimental kidney was expressed as a fraction of its control.
This indicates that the changes in the composition of blood perfusing the experimental kidney caused the changes in vascular resistance. However, the magnitude of the changes in RBF were generally reduced when expressed as a fraction of the control kidney, indicating that the infusions caused similar, although smaller, changes in RBF of the control kidneys, presumably in response to the small changes in composition of the systemic blood.

There was no significant correlation between the group mean changes in $\mathrm{RBF}$ and changes in $P_{\mathrm{Na}}$ $(r=0.18 ; n=6$; NS). However, there was a very close correlation between group mean changes in RBF and changes in $\mathrm{P}_{\mathrm{Cl}}(r=-0.91 ; n=6 ; P<0.01)$.

Relationships between changes in $R B F$ and fractional reabsorption of fluid, $\mathrm{Na}^{+}$or $\mathrm{Cl}^{-}$. To examine the hypothesis that changes in GFR or RBF during osmotic diuresis are mediated by inhibition of tubular fluid reabsorption (12-14), the group mean changes in $\mathrm{RBF}$ and GFR produced by the hypertonic infusions were compared to changes in fractional reabsorption of fluid $\left(R / F_{\mathrm{H}_{2} \mathrm{O}}\right)$. No significant correlations were apparent between group mean changes in $R / F_{\mathrm{H}_{2} \mathrm{O}}$ and either RBF (Fig. 2A) or GFR ( $r=0.37$; NS).

During osmotic diuresis or during administration of $\mathrm{NH}_{4} \mathrm{Cl}$ or hypertonic $\mathrm{NaCl}$ administration, there is considerable inhibition of proximal tubular reabsorption of fluid, $\mathrm{Na}^{+}$and $\mathrm{Cl}^{-}(17-22)$. Consequently, the changes in the fractional reabsorption of sodium ( $R$ / $\left.\mathrm{F}_{\mathrm{Na}}\right)$ or chloride $\left(\mathrm{R} / \mathrm{F}_{\mathrm{Cl}}\right)$ during these infusions indicate the delivery of filtered $\mathrm{Na}^{+}$and $\mathrm{Cl}^{-}$to the loop of Henle. To examine the hypothesis that changes in GFR or $\mathrm{RBF}$ were related to changes in the delivery of 
TABLE II

Changes in Renal Hemodynamics during Hypertonic Intrarenal Infusions

\begin{tabular}{|c|c|c|c|c|c|}
\hline \multirow[b]{2}{*}{ Solution } & \multirow{2}{*}{$\begin{array}{c}\text { Before } \\
\text { compared } \\
\text { with }\end{array}$} & \multicolumn{4}{|c|}{ \% Change } \\
\hline & & RBF & RPF & GFR & $\mathbf{F F}$ \\
\hline \multirow[t]{2}{*}{$\begin{array}{r}\mathrm{NaHCO}_{3} \\
\quad(n=5)\end{array}$} & During & $\begin{array}{l}+9.7 \pm 8.5 \\
P<0.05\end{array}$ & $\begin{array}{c}+11.0 \pm 8.8 \\
P<0.05\end{array}$ & $\begin{array}{c}-9.7 \pm 10.5 \\
\text { NS }\end{array}$ & $\begin{array}{c}-21.4 \pm 12.7 \\
P<0.05\end{array}$ \\
\hline & After & $\begin{array}{c}+4.5 \pm 11.2 \\
\text { NS }\end{array}$ & $\begin{array}{c}+7.3 \pm 11.6 \\
\text { NS }\end{array}$ & $\begin{array}{c}+2.2 \pm 14.5 \\
\text { NS }\end{array}$ & $\begin{array}{c}-4.4 \pm 9.3 \\
\text { NS }\end{array}$ \\
\hline \multirow[t]{2}{*}{$\begin{array}{l}\text { Na Acetate } \\
\quad(n=6)\end{array}$} & During & $\begin{array}{c}+27.6 \pm 17.7 \\
P<0.02\end{array}$ & $\begin{array}{c}+27.6 \pm 15.3 \\
P<0.01\end{array}$ & $\begin{array}{c}-13.7 \pm 25.3 \\
\text { NS }\end{array}$ & $\begin{array}{r}-29.0 \pm 12.6 \\
P<0.005\end{array}$ \\
\hline & After & $\begin{array}{c}+5.6 \pm 18.7 \\
\text { NS }\end{array}$ & $\begin{array}{c}+6.8 \pm 17.6 \\
\text { NS }\end{array}$ & $\begin{array}{c}-10.0 \pm 11.9 \\
\text { NS }\end{array}$ & $\begin{array}{r}-16.4 \pm 12.8 \\
P<0.025\end{array}$ \\
\hline \multirow[t]{2}{*}{$\begin{array}{l}\text { Dextrose } \\
\qquad(n=9)\end{array}$} & During & $\begin{array}{c}+14.7 \pm 13.1 \\
P<0.01\end{array}$ & $\begin{array}{c}+20.5 \pm 13.9 \\
P<0.005\end{array}$ & $\begin{array}{c}-8.4 \pm 21.0 \\
\text { NS }\end{array}$ & $\begin{array}{c}-21.3 \pm 12.7 \\
P<0.05\end{array}$ \\
\hline & After & $\begin{array}{c}-8.8 \pm 14.6 \\
\text { NS }\end{array}$ & $\begin{array}{c}-9.0 \pm 14.3 \\
\text { NS }\end{array}$ & $\begin{array}{c}+2.2 \pm 14.5 \\
\text { NS }\end{array}$ & $\begin{array}{c}-4.4 \pm 9.3 \\
\text { NS }\end{array}$ \\
\hline \multirow[t]{2}{*}{$\begin{array}{c}\mathrm{NH}_{4} \text { Acetate } \\
\quad(n=5)\end{array}$} & During & $\begin{array}{c}+4.8 \pm 26.4 \\
\text { NS }\end{array}$ & $\begin{array}{c}-5.2 \pm 20.1 \\
\text { NS }\end{array}$ & $\begin{array}{c}-25.6 \pm 28.0 \\
\text { NS }\end{array}$ & $\begin{array}{r}-23.8 \pm 7.8 \\
P<0.01\end{array}$ \\
\hline & After & $\begin{array}{c}+26.0 \pm 29.9 \\
\text { NS }\end{array}$ & $\begin{array}{c}+40.8 \pm 49.4 \\
\text { NS }\end{array}$ & $\begin{array}{c}-9.1 \pm 27.9 \\
\text { NS }\end{array}$ & $\begin{array}{r}-33.6 \pm 12.7 \\
P<0.005\end{array}$ \\
\hline \multirow[t]{2}{*}{$\begin{array}{l}\mathrm{NaCl} \\
\quad(n=17)\end{array}$} & During & $\begin{array}{r}-14.4 \pm 9.2 \\
P<0.001\end{array}$ & $\begin{array}{l}-7.2 \pm 10.3 \\
P<0.01\end{array}$ & $\begin{array}{l}-9.4 \pm 11.4 \\
P<0.005\end{array}$ & $\begin{array}{c}-1.9 \pm 7.6 \\
\text { NS }\end{array}$ \\
\hline & After & $\begin{array}{c}-5.9 \pm 13.0 \\
\text { NS }\end{array}$ & $\begin{array}{c}+1.6 \pm 16.9 \\
\text { NS }\end{array}$ & $\begin{array}{c}+0.5 \pm 15.9 \\
\text { NS }\end{array}$ & $\begin{array}{c}+1.2 \pm 17.1 \\
\text { NS }\end{array}$ \\
\hline \multirow[t]{2}{*}{$\begin{array}{l}\mathrm{NH}_{4} \mathrm{Cl} \\
\quad(n=6)\end{array}$} & During & $\begin{array}{c}-44.4 \pm 23.7 \\
P<0.01\end{array}$ & $\begin{array}{c}-48.0 \pm 21.1 \\
P<0.005\end{array}$ & $\begin{array}{c}-62.2 \pm 14.6 \\
P<0.001\end{array}$ & $\begin{array}{c}-26.4 \pm 6.2 \\
P<0.001\end{array}$ \\
\hline & After & $\begin{array}{c}-1.0 \pm 25.3 \\
\text { NS }\end{array}$ & $\begin{array}{c}-5.0 \pm 25.9 \\
\text { NS }\end{array}$ & $\begin{array}{c}-20.7 \pm 18.7 \\
P<0.05\end{array}$ & $\begin{array}{c}-6.0 \pm 16.4 \\
\text { NS }\end{array}$ \\
\hline
\end{tabular}

Mean ( \pm SD) percentage changes in RPF, GFR, FF, and RBF 15-30 min after starting and 15-30 min after completion of the infusion of $1.232 \mathrm{M}$ solutions compared to values before these infusions. The mean $\pm \mathrm{SD}$ initial values for the entire group were as follows: RBF, $9.43 \pm 3.12 \mathrm{ml} \mathrm{min}^{-1} \mathrm{~kg}_{\text {body }} \mathrm{wt}^{-1} ; \mathrm{RPF}, 4.73 \pm 1.51 \mathrm{ml} \mathrm{min}^{-1}$ kg body $\mathrm{wt}^{-1}$; GFR, 1.39 $\pm 0.40 \mathrm{ml} \mathrm{min}^{-1} \mathrm{~kg}$ body $\mathrm{wt}^{-1}$; FF, 29.6 $\pm 5.9 \%$.

filtered $\mathrm{Na}^{+}(6)$ or $\mathrm{Cl}^{-}(8)$ to the loop of Henle, the relationships between $\mathrm{RBF}$ and either $\mathrm{R} / \mathrm{F}_{\mathrm{Na}}$ or $\mathrm{R} / \mathrm{F}_{\mathrm{Cl}}$ are presented in Fig. $2 B$ and $C$. There were no significant correlations between group mean changes in $\mathrm{R} / \mathrm{F}_{\mathrm{Na}}$ and RBF (Fig. 2B) or GFR ( $r=0.45$; NS). In contrast, there were very close relationships between group mean changes in $\mathrm{R} / \mathrm{F}_{\mathrm{Cl}}$ and $\mathrm{RBF}$ (Fig. $2 \mathrm{C}$ ) or GFR $(r=0.81 ; P<0.05)$.

Since all infusions increased $P_{\text {osmol }}$, yet some led to renal vasodilatation and others to renal vasoconstriction, it is clear that the steady-state changes in renal vascular resistance were independent of $P_{\text {osmol }}$.
Time course of changes in RBF during hypertonic infusions. Fig. 3 shows the records of RBF, MAP, and urine flow from two experiments during the infusion of hypertonic solutions of $\mathrm{Na}$ acetate $(\mathrm{A})$ and $\mathrm{NH}_{4} \mathrm{Cl}$ (B). Within the first 2-3 min of starting both infusions, there was an increase in RBF without a rise in MAP indicating renal vasodilatation. However, during the subsequent $30 \mathrm{~min}$, opposite changes in renal vascular resistance occurred. Thus, with $\mathrm{Na}$ acetate, $\mathrm{RBF}$ increased progressively from 220 to $380 \mathrm{ml} \mathrm{min}^{-1}$. In contrast, with $\mathrm{NH}_{4} \mathrm{Cl}, \mathrm{RBF}$ fell sharply from 480 to $190 \mathrm{ml} \mathrm{min}^{-1}$. Both changes were reversed by $\sim 15$ 


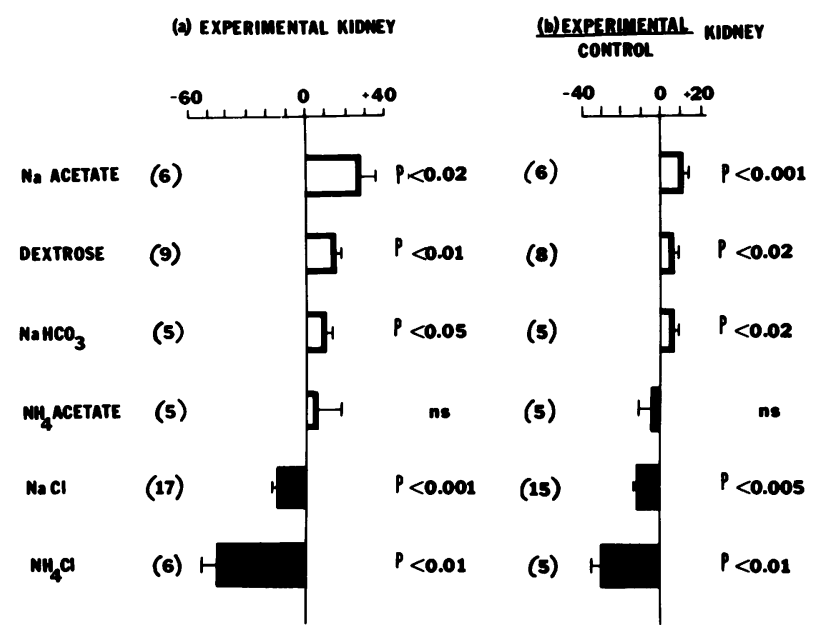

Figure 1 Mean ( \pm SEM) values with number of observations in parentheses for (a) percentage change in $\mathrm{RBF}$ at the experimental kidney during the period 15-30 min after starting $1.232 \mathrm{M}$ intrarenal infusions of the solutions shown and (b) percentage changes in renal blood flow at the experimental kidney compared to the control kidney during these infusions. The $P$ value refers to results of paired $t$ tests. The mean $( \pm S D)$ starting values for the entire group were: $R B F$, $9.43 \pm 3.12 \mathrm{ml} \mathrm{min}^{-1} \mathrm{~kg}$ body $\mathrm{wt}^{-1}$; experimental/control RBF, 97.7 $\pm 17.1 \%$.

min after stopping the hypertonic infusions. The infusion of $\mathrm{Na}$ acetate reduced urine flow rate, whereas the $\mathrm{NH}_{4} \mathrm{Cl}$ increased it initially, although by the end of the infusion when GFR had fallen sharply, urine flow rate also fell.

The time course of changes in $\mathrm{RBF}$ were assessed from the electromagnetic flow meter records. Percentage changes in RBF at 1-2 min and at $30 \mathrm{~min}$ after starting the infusions are shown in Table III. Within 1-2 min of starting the infusions of the different hypertonic solutions, RBF increased in 45 of 46 experiments. Compared with the $10.3 \%$ mean increase in RBF after 2 min of dextrose infusion, the rise of $35.2 \%$ with $\mathrm{Na}$ acetate was significantly greater $(P<0.02)$, but the early increase in RBF with the other solutions was not different. Thereafter, RBF increased further during the infusion of dextrose and $\mathrm{NaHCO}_{3}$; with $\mathrm{Na}$ acetate, the RBF increased further in six of seven experiments. During $\mathrm{NH}_{4}$ acetate, there was a large initial rise in RBF that returned towards (but not below) preinfusion values.

The infusion of the two Cl-containing solutions produced an early increase in RBF that was strictly comparable to that seen with the other hypertonic solutions. In contrast, however, in each of the 21 experiments, RBF declined over the period 1-30 min during the infusion of the $\mathrm{Cl}$-containing solutions. By $30 \mathrm{~min}$, RBF was reduced significantly below preinfusion levels with both $\mathrm{NaCl}$ and $\mathrm{NH}_{4} \mathrm{Cl}$; the fall in $\mathrm{RBF}$ was greater with $\mathrm{NH}_{4} \mathrm{Cl}$ than with $\mathrm{NaCl}(P<0.01)$.

Effects of prior salt depletion on hemodynamic response to hypertonic $\mathrm{NaCl}$ infusions. The effects of prior salt and fluid depletion on the renal hemodynamic response to hypertonic $\mathrm{NaCl}$ infusions was assessed by comparing the changes produced by intrarenal infusion of hypertonic $\mathrm{NaCl}$ in 17 "euvolemic" dogs with those of five "Na-depleted" dogs. As shown in Table IV, the Na-depleted dogs had a higher FF and a tendency for a lower RPF before the infusion.
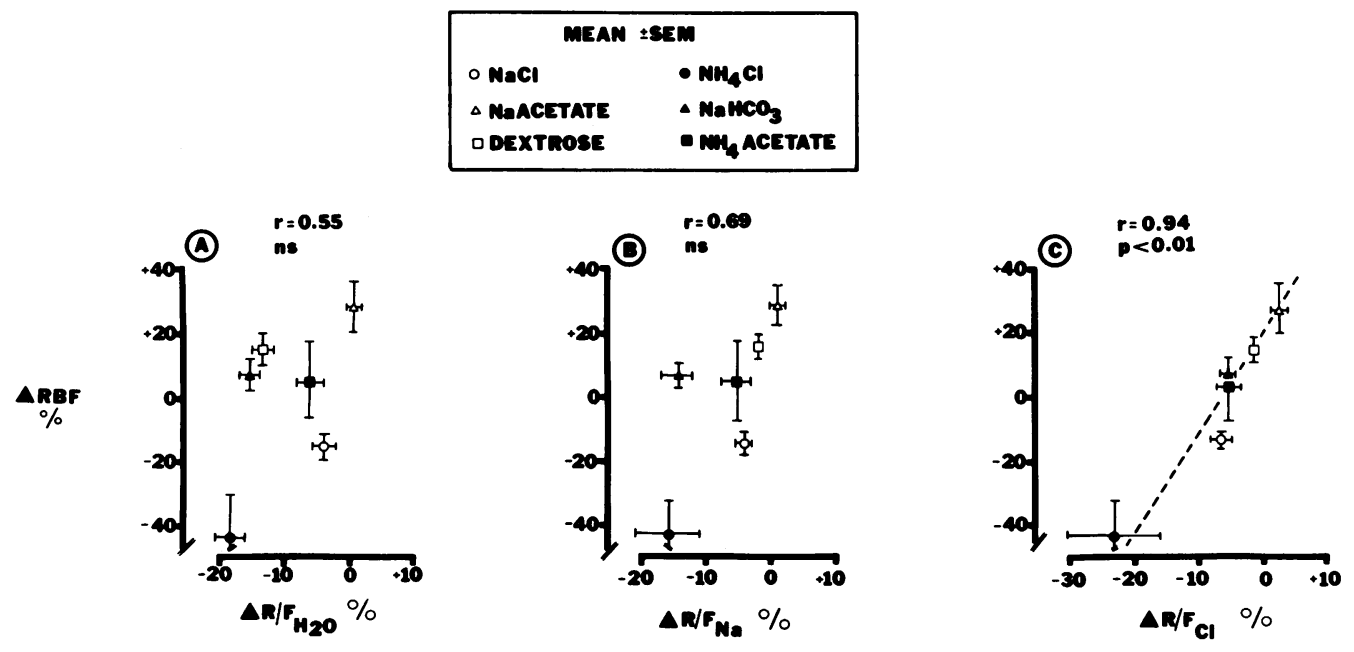

FigURE 2 Group mean ( \pm SEM) values for percentage changes in renal blood flow are shown as a function of changes in: (A) fractional water reabsorption, (B) fractional sodium reabsorption, and $(C)$ fractional chloride reabsorption. 


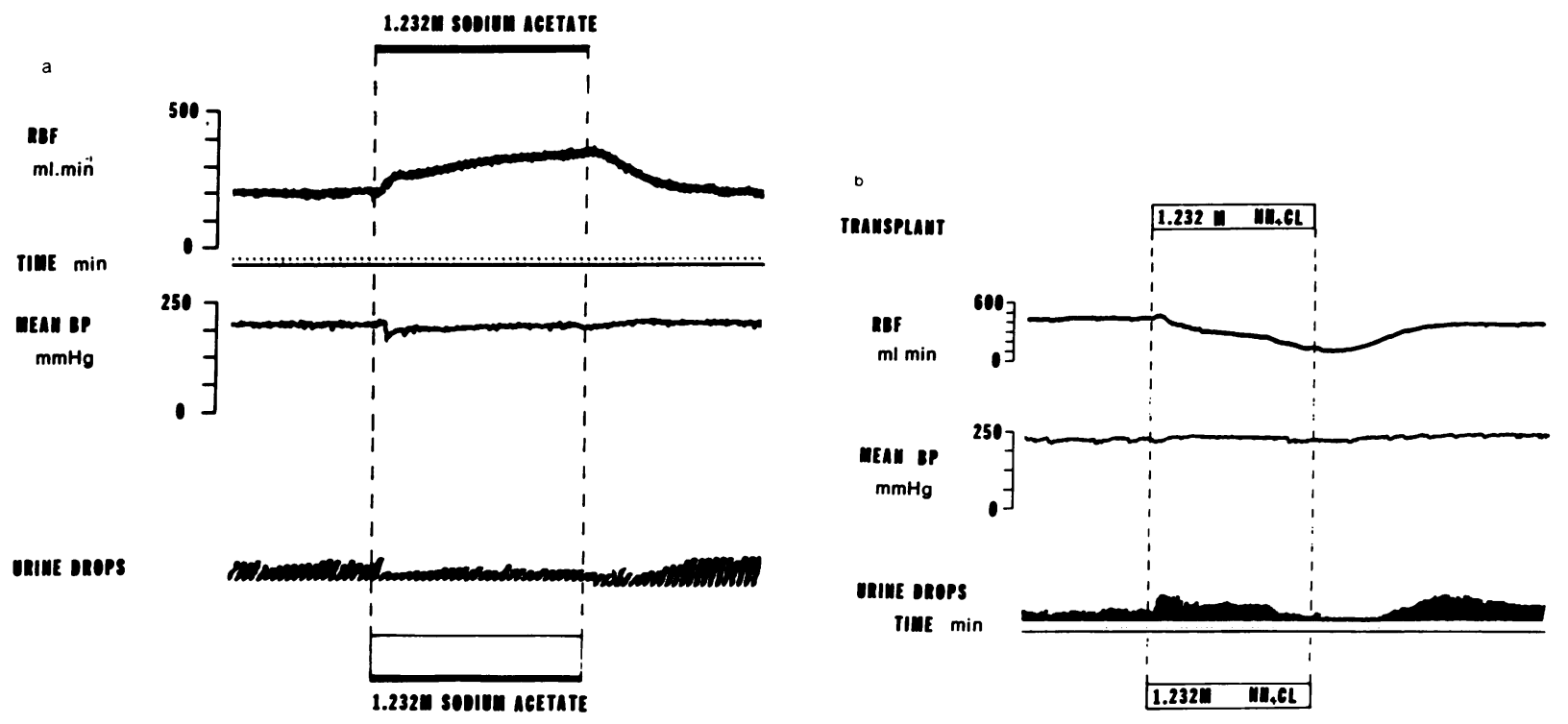

FIGURE 3 Records of two experiments showing the mean RBF recorded with a flow meter, mean $\mathrm{BP}$ and urine drop rate. An intrarenal isotonic $\mathrm{NaCl}$ infusion was switched to a 1.232 $\mathrm{M}$ infusion of (a) $\mathrm{Na}$ acetate and (b) $\mathrm{NH}_{4} \mathrm{Cl}$ during the periods shown.

During $\mathrm{NaCl}$ infusion, the falls in RBF, RPF, and GFR in the salt-depleted dogs were more than twice as great as in the euvolemic dogs, but there were no changes in FF or blood pressure (BP) in either group. Thus, salt depletion augmented the renal vasoconstriction that developed with hypertonic $\mathrm{NaCl}$ infusions.

FBF during intraarterial infusions of hypertonic solutions. In four experiments, the same six hypertonic solutions were infused into the femoral artery. All six hypertonic solutions led to an abrupt increase in FBF that was maintained for the 15-min infusion periods. Since mean BP did not change, femoral vascular resistance declined during the infusion of each of the solutions.

\section{DISCUSSION}

Infusion of hypertonic solutions into the renal artery caused a biphasic response in renal vascular resistance. The hyperosmolality invariably led to an abrupt renal vasodilatation. Acute vasodilatation, in response to hyperosmolality, is seen at other vessels besides the kidney (9-11, 23, 24), including the aorta (25), intact and isolated muscle arteries (26-30), the pulmonary (31), the mesenteric (10) and the coronary (30), although this response is not always fully maintained (30). Gazitua et al. (32) contrasted the changes in renal vascular resistance produced by hypertonic dextrose and $\mathrm{NaCl}$. As in the present study, they found that both produced an initial fall in resistance but, whereas this vasodilatation was maintained during the 3-min infusion of dextrose, vasoconstriction developed with $\mathrm{NaCl}$. In the present study, only $\mathrm{NaHCO}_{3}$ failed to elicit a significant early rise in RBF. This may have been due to alkalosis since this has been shown to potentiate calcium-activated vascular contraction $(33,34)$.

The addition of hypertonic solutions to blood causes an abrupt shrinkage of erythrocytes that restricts their deformality and increases the blood viscosity $(35,36)$. In the present experiment, however, an increase in plasma tonicity led to an abrupt reduction in renal vascular resistance and therefore, changes in blood viscosity could only have limited the increase in RBF.

Late changes in renal vascular resistance. The uniform early renal vasodilatation during intrarenal infusions of various hypertonic solutions was succeeded by strikingly different patterns of renal vascular resistance that depended on the composition of the infusate. The infusion of dextrose, $\mathrm{NaHCO}_{3}$, and $\mathrm{Na}$ acetate led to persistent or progressive renal vasodilatation; $\mathrm{NH}_{4}$ acetate did not change renal vascular resistance consistently. Thus, hypertonic solutions can cause a sustained renal vasodilatation regardless of whether they increase $P_{\mathrm{Na}}$. In marked contrast, in each of the 21 experiments during which $\mathrm{P}_{\mathrm{Cl}}$ was increased, renal vasoconstriction occurred after the initial vasodilatation.

We showed previously that the degree of renal vasodilatation that occurred during more prolonged infusions of hypertonic $\mathrm{NaCl}$ was dependent upon the accompanying metabolic acidosis (9). In the present 
TABLE III

Changes in RBF during Intrarenal Arterial Infusions of Hypertonic Solutions

\begin{tabular}{|c|c|c|c|}
\hline & \multirow[b]{2}{*}{$n$} & \multicolumn{2}{|c|}{ Percentage changes in RBF during infusion of hypertonic solution } \\
\hline & & After $1 \mathrm{~min}$ of infusion & After $30 \mathrm{~min}$ of infusion \\
\hline $\begin{array}{l}\text { Dextrose } \\
\text { During vs. before } \\
30 \mathrm{~min} \text { vs. } 1 \mathrm{~min}\end{array}$ & 7 & $\begin{array}{r}+10.3 \pm 5.1 \\
P<0.005\end{array}$ & $\begin{array}{r}+14.4 \pm 6.0 \\
P<0.001\end{array}$ \\
\hline $\begin{array}{l}\text { Na Acetate } \\
\text { During vs. before } \\
30 \mathrm{~min} \text { vs. } 1 \mathrm{~min}\end{array}$ & 8 & $\begin{array}{c}+35.2 \pm 23.5 \\
P<0.005\end{array}$ & $\begin{array}{c}+50.7 \pm 23.4 \\
P<0.001\end{array}$ \\
\hline $\begin{array}{l}\mathrm{NaHCO}_{3} \\
\text { During vs. before } \\
30 \mathrm{~min} \text { vs. } 1 \mathrm{~min}\end{array}$ & 5 & $\begin{array}{c}+10.8 \pm 11.7 \\
\text { NS }\end{array}$ & $\begin{array}{c}+20.8 \pm 16.1 \\
P<0.05\end{array}$ \\
\hline $\begin{array}{l}\mathrm{NH}_{4} \text { Acetate } \\
\text { During vs. before } \\
30 \text { min vs. } 1 \text { min }\end{array}$ & 5 & $\begin{array}{c}+25.6 \pm 20.5 \\
P<0.05\end{array}$ & $\begin{array}{l}+2.3 \pm 29.3 \\
\text { NS }\end{array}$ \\
\hline $\begin{array}{l}\mathrm{NaCl} \\
\text { During vs. before } \\
30 \mathrm{~min} \text { vs. } 1 \mathrm{~min}\end{array}$ & 14 & $\begin{array}{r}+11.4 \pm 4.9 \\
P<0.001\end{array}$ & $\begin{array}{c}-12.5 \pm 12.6 \\
P<0.005\end{array}$ \\
\hline $\begin{array}{l}\mathrm{NH}_{4} \mathrm{Cl} \\
\quad \text { During vs. before } \\
30 \text { min vs. } 1 \text { min }\end{array}$ & 7 & $\begin{array}{c}+18.6 \pm 11.3 \\
P<0.005\end{array}$ & $\begin{array}{c}-41.3 \pm 22.5 \\
P<0.005\end{array}$ \\
\hline
\end{tabular}

Data represent changes in $\mathrm{RBF}($ mean $\pm \mathrm{SD}$ ) at the experimental kidney as measured with an electromagnetic flow meter. Values refer to percentage changes at 1 and 30 min after starting the infusions of $1.232 \mathrm{M}$ solutions compared to values recorded immediately before the hypertonic infusions. The $P$ values refer to results of paired $t$ tests; $n=$ number of experiments.

TABLE IV

Effects of Prior Salt Depletion on Renal Vascular Response to Intrarenal Hypertonic NaCl Infusion

\begin{tabular}{|c|c|c|c|c|c|}
\hline \multirow[b]{2}{*}{$\begin{array}{l}\text { RBF, } \\
\quad m l \min ^{-1} k^{-1}\end{array}$} & \multirow{2}{*}{$\begin{array}{c}\begin{array}{c}\text { Prior salt } \\
\text { depletion }\end{array} \\
\begin{array}{l}\text { No } \\
\text { Yes }\end{array}\end{array}$} & \multicolumn{2}{|c|}{ Value before } & \multicolumn{2}{|c|}{$\begin{array}{l}\text { \% Change during hypertonic } \\
\mathrm{NaCl} \text { infusion }\end{array}$} \\
\hline & & $\begin{array}{l}9.43 \pm 3.12 \\
9.31 \pm 1.21\end{array}$ & NS & $\begin{array}{l}-14 \pm 9 \\
-29 \pm 13\end{array}$ & $<0.0125$ \\
\hline $\begin{array}{l}\text { RPF, } \\
\quad m l \min ^{-1} k^{-1}\end{array}$ & $\begin{array}{l}\text { No } \\
\text { Yes }\end{array}$ & $\begin{array}{l}4.73 \pm 1.51 \\
3.88 \pm 1.18\end{array}$ & NS & $\begin{array}{r}-7 \pm 10 \\
-20 \pm 11\end{array}$ & $<0.05$ \\
\hline $\begin{array}{l}\text { GFR, } \\
\quad m l \min ^{-1} k^{-1}\end{array}$ & $\begin{array}{l}\text { No } \\
\text { Yes }\end{array}$ & $\begin{array}{l}1.37 \pm 0.38 \\
1.43 \pm 0.52\end{array}$ & NS & $\begin{array}{l}-9 \pm 11 \\
-25 \pm 8\end{array}$ & $<0.005$ \\
\hline $\begin{array}{l}\text { FF, } \\
\quad \%\end{array}$ & $\begin{array}{l}\text { No } \\
\text { Yes }\end{array}$ & $\begin{array}{l}29.6 \pm 5.9 \\
36.4 \pm 3.2\end{array}$ & $<0.005$ & $\begin{array}{l}-2 \pm 8 \\
-5 \pm 9\end{array}$ & NS \\
\hline $\begin{array}{l}\text { MAP, } \\
\qquad m m H g\end{array}$ & $\begin{array}{l}\text { No } \\
\text { Yes }\end{array}$ & $\begin{array}{l}164 \pm 23 \\
165 \pm 15\end{array}$ & NS & $\begin{array}{l}-2 \pm 10 \\
-1 \pm 6\end{array}$ & NS \\
\hline
\end{tabular}

Mean \pm SD values for renal clearance and mean arterial pressure in dogs without prior salt depletion $(n=17)$ compared to those with salt depletion $(n=5)$. Shown are the values recorded before the hypertonic infusion and the percentage changes occurring 15-30 min during the infusion. 
series, $\mathrm{P}_{\mathrm{H}}$ was higher and $\mathrm{RBF}$ was lower during the infusions of the two $\mathrm{NH}_{4}$-containing solutions than during the infusion of the corresponding $\mathrm{Na}$-containing solutions. This suggests that the vasoconstriction occurring with $\mathrm{NH}_{4}{ }^{+}$infusions could be related to metabolic acidosis $(21,37)$. The same pattern of changes in renal vascular resistance was apparent when the RBF at the experimental kidney was factored by that at the control kidney. This suggests that the renal vasoconstriction during the infusion of $\mathrm{Cl}$-containing solutions was related to the local increase in $\mathrm{P}_{\mathrm{Cl}}$ that was potentiated by an accompanying rise in $P_{H}$.

Prior salt depletion doubled the renal vasoconstriction that occurred during intrarenal hypertonic $\mathrm{NaCl}$ infusion. Gerber et al. (10) showed that acute volume expansion with isotonic saline abolished renal vasoconstriction during hypertonic $\mathrm{NaCl}$ infusions. An uncontrolled salt intake might explain why renal vasoconstriction was not seen with hypertonic $\mathrm{NaCl}$ infusion in one previous study (24). Several other studies have demonstrated vasoconstriction during infusion of hypertonic $\mathrm{NaCl}$ solutions in intact and isolated kidneys $(9-11,32)$.

The intrarenal infusion of all the hypertonic solutions that did not contain $\mathrm{Cl}^{-}$(except for $\mathrm{NH}_{4}$ acetate) produced an increase in RPF but no significant changes in GFR; the FF fell in every case indicating that the renal vasodilatation probably affected afferent and efferent arterioles (38). In contrast, the GFR was reduced during the intrarenal infusion of the two $\mathrm{Cl}$ containing solutions. With $\mathrm{NaCl}$, the fall in GFR was proportional to the fall in RPF and the FF remained unchanged, suggesting that the vasoconstriction affected afferent and efferent arterioles. With $\mathrm{NH}_{4} \mathrm{Cl}$, however, the FF fell considerably suggesting an additional effect on the glomerular ultrafiltration coefficient (39).

There are several similarities between the Cl-induced fall in RBF and GFR observed in these experiments and the "tubulo-glomerular feedback" mechanism identified at the single nephron level and that is initiated by tubular $\mathrm{Cl}^{-}$reabsorption $(8,40-42)$. Some experiments have indicated that tubular fluid osmolality may also regulate the nephron feedback response although this remains controversial $(4,43)$. "Feedback inhibition" of SNGFR occurs during infusion of hypertonic $\mathrm{NaCl}$ but not hypertonic $\mathrm{NaHCO}_{3}$ (44), is augmented by prior dietary salt restriction (45), and is independent of the nervous system (46). In one series, feedback inhibition of SNGFR was accompanied by a rise in FF (47) but in a recent study, Ichikawa has shown that although feedback inhibition of SNGFR is accompanied by comparable increases in afferent and efferent arteriolar resistance, the FF falls because
SNGFR is reduced not only by the fall in plasma flow rate, but also by a large fall in the glomerular capillary ultrafiltration coefficient (39). In the present series, sustained renal vasoconstriction was specifically related to hyperchloremia, was related to $\mathrm{Cl}^{-}$reabsorption, was initiated by an intrarenal mechanism that was independent of the nervous system, was potentiated by prior salt depletion, was specific for the kidney, and was accompanied by a fall in GFR. We observed no change in FF during $\mathrm{Cl}$-induced renal vasoconstriction with $\mathrm{NaCl}$ infusion, but a fall in FF during $\mathrm{NH}_{4} \mathrm{Cl}$. The $\mathrm{NH}_{4} \mathrm{Cl}$ produced a hyperchloremic acidosis, which has been found to impair proximal tubule $\mathrm{Na}^{+}-\mathrm{K}^{+}$transport $(21,22)$, leads to enhanced delivery of filtrate to the distal nephron (48) and increases $U_{\mathrm{Na}} \mathrm{V}(21,23,37)$. The greater vasoconstriction apparent with $\mathrm{NH}_{4} \mathrm{Cl}$ than with $\mathrm{NaCl}$ in the present series and the potentiation of $\mathrm{NaCl}$-induced renal vasoconstriction by metabolic acidosis observed previously (49) may be related to inhibition of proximal fluid reabsorption during metabolic acidosis with a consequent increase in distal $\mathrm{Cl}^{-}$delivery and potentiation of the feedback response. Thus, the present studies extend the micropuncture findings to the whole kidney level, demonstrate the specificity of hyperchloremic vasoconstriction for the kidney and indicate a physiological role for the feedback mechanism in regulating renal vascular resistance during hyperchloremia and metabolic acidosis.

The predominant effects of hypertonic infusions on salt and water reabsorption should occur in the proximal tubule. In the isolated tubule, an increase in the $\mathrm{NaCl}$ concentration of the perfusate inhibits fluid reabsorption (20). In the intact animal, $\mathrm{NH}_{4} \mathrm{Cl}$ or hypertonic $\mathrm{NaCl}$ inhibits proximal reabsorption of fluid, $\mathrm{Na}^{+}$ and $\mathrm{Cl}^{-}$and increases the early distal $\mathrm{NaCl}$ concentration $(48,50)$ whereas hypertonic $\mathrm{NaHCO}_{3}$ decreases early distal $\mathrm{Cl}^{-}$concentration (51). Thus, infusions of $\mathrm{NH}_{4} \mathrm{Cl}$ or $\mathrm{NaCl}$ will increase substantially the fraction of filtrate delivered to the loop of Henle $(17,21,22)$. Accordingly, changes in $\mathbf{R} / \mathbf{F}_{\mathrm{Na}}$ or $\mathbf{R} / \mathbf{F}_{\mathrm{Cl}}$ should indicate changes in distal delivery of filtered $\mathrm{Na}^{+}$and $\mathrm{Cl}^{-}$. The changes in RBF and GFR were independent of changes in $R / F_{\mathrm{Na}}$ but were very closely correlated with changes in $R / F_{C l}$ (Fig. $2 B$ and $2 C$ ), suggesting that renal vascular resistance was related to the delivery of $\mathrm{Cl}^{-}$, but not $\mathrm{Na}^{+}$, to the loop of Henle. Nizet found that the GFR fell during osmotic diuresis or inhibition of proximal-tubular function but that this was related to a fall in $\mathrm{R} / \mathrm{F}_{\mathrm{H}_{2} \mathrm{O}}$ and was independent of $\mathrm{Cl}^{-}$reabsorption (12-14). His studies were conducted during a considerable osmotic diuresis that may have increased the intratubular and intrarenal pressures and could have led to passive falls in GFR and RBF. In our studies, the osmotic diuresis was less severe and 
changes in GFR or RBF were independent of $R / F_{\mathrm{H}_{2} \mathrm{O}}$ (Fig. 2A). Whereas Nizet (12) found that $\mathrm{Na}_{2} \mathrm{SO}_{4}$, but not $\mathrm{NaCl}$, reduced RBF, Sadowski (11) obtained opposite results using rates of osmolar infusion similar to those in the present experiments. Thus, the mechanisms identified by Nizet to regulate GFR and RBF probably operate at high rates of osmotic diuresis. The present study demonstrates that the regulation of RBF and GFR by $\mathrm{Cl}^{-}$can override the effects of hyperosmolality on the renal circulation.

\section{ACKNOWLEDGMENTS}

The author gratefully acknowledges a Pharmaceutical Manufacturer's Faculty Award and a grant from the National Institutes of Health AM 27952. We thank Miss Paula Dolan for typing the manuscript.

\section{REFERENCES}

1. Thurau, K. 1964. Renal hemodynamics. Am. J. Med. 36: 698-719.

2. McDougal, W. S., and F. S. Wright. 1972. Defect in proximal and distal sodium transport in post-obstructive diuresis. Kidney Int. 2: 304-317.

3. Ploth, D. W., J. Schnermann, H. Dalheim, M. Hermle, and E. Schmidmeier. 1977. Autoregulation and tubuloglomerular feedback in normotensive and hypertensive rats. Kidney Int. 12: 253-267.

4. Wright, F. S., and J. P. Briggs. 1977. Feedback regulation of glomerular filtration rate. Am. J. Physiol. 233: F1-F7.

5. Tucker, B. J., R. W. Steiner, L. C. Gushwa, and R. C. Blantz. 1978. Studies on the tubulo-glomerular feedback system in the rat. The mechanism of reduction in filtration rate with benzolamide. J. Clin. Invest. 62: 9931004.

6. Thurau, K., and J. Schnermann. 1965. Die Natriumkonzentration an der Macula densa Zellen als regulierender Faktar fur das Glomerulum filtrat. Klin. Wochenschr. 43: 410-413.

7. Guyton, A. C., J. B. Langston, and L. G. Navar. 1964. Theory for renal autoregulation by feedback of the juxtaglomerular apparatus. Circ. Res. 15(Suppl.): 187-196.

8. Schnermann, J., D. W. Ploth, and M. Hermle. 1976. Activation of tubuloglomerular feedback by chloride transport. Pfluegers Arch. Eur. J. Physiol. 362: 229-240.

9. Nashat, F. S., J. W. Tappin, and C. S. Wilcox. 1976. The renal blood flow and the glomerular filtration rate of anesthetized dogs during acute changes in plasma sodium concentration. J. Physiol. 256: 731-745.

10. Gerber, J. G., R. A. Branch, A. S. Nies, J. W. Hollifield, and J. F. Gerkens. 1979. Influence of hypertonic saline on canine renal blood flow and renin release. Am. J. Physiol. 237: F441-F446.

11. Sadowski, J. 1972. Effects of renal artery infusion of various hypertonic solutions on the renal blood flow and renal handling of PAH in the dog. Pfluegers Arch. Eur. J. Physiol. 334: 85-102.

12. Nizet, A. 1979. Influence of replacement of chloride by sulphate upon urine excretion and glomerular filtration rate in blood-perfused dog kidneys. Pfluegers Arch. Eur. J. Physiol. 382: 217-223.
13. Nizet, A. 1981. Connection between the changes in tubular reabsorption and in glomerular filtration rate induced by replacement of plasma sodium and chloride by isotonic mannitol. Arch. Int. Physiol. Biochim. 89: 35-40.

14. Nizet, A. 1981. Influence of uranyl nitrate upon tubular reabsorption and glomerular filtration in blood-perfused isolated dog kidneys. Pfluegers Arch. Eur. J. Physiol. 391: 296-300.

15. Wilcox, C. S. 1976. A denervated dog's kidney preparation for studying the actions of drugs or hormones on renal function and renal lymph formation. J. Physiol. 265: 6-7P.

16. Wilcox, C. S. 1978. The effect of increasing the plasma magnesium concentration on renin release from the dog's kidney: interactions with calcium and sodium. $J$. Physiol. 284: 203-217.

17. Giebisch, G., R. M. Klose, and E. E. Windhager. 1964. Micropuncture study of hypertonic sodium chloride loading in the rat. Am. J. Physiol. 206: 687-693.

18. Koch, K. M., T. Dume, H. H. Krause, and B. Ochwadt. 1967. Intratubularer Druck, glomerularer Capillardruck und Glomerulumfiltrat wahrend mannitoldiurese. Pfuegers Arch. Eur. J. Physiol. 295: 72-79.

19. Dubb, J., M. Goldberg, and Z. S. Agus. 1977. Tubular effects of acute metabolic acidosis in the rat. J. Lab. Clin. Med. 90: 318-323.

20. Corman, B., S. Carriere, C. Le Grimellec, and J. Cardinal. 1980. Proximal tubular response to variations in extracellular sodium concentration. Am. J. Physiol. 238: F256-F260.

21. Wilcox, C. S. 1981. The renal response to salt loading. In Advances in Medical Science; Kidney and Body Fluids. L. Takas, editor. Pergamon Press, International Union Physiol. Sci., 11, pp. 621-629.

22. Cemerikic, D., C. S. Wilcox, and G. Giebisch. 1982. Intracellular potential and $\mathrm{K}+$ activity in rat kidney proximal tubular cells in acidosis and $\mathrm{K}+$ depletion. $J$. Membr. Biol. In press.

23. Harvey, R. B. 1960. Vascular resistance changes produced by hyperosmotic solutions. Am. J. Physiol. 199: 31-34.

24. Navar, L. G., A. C. Guyton, and J. B. Langston. 1966. Effect of alterations in plasma osmolality on renal blood flow autoregulation. Am. J. Physiol. 211: 1387-1392.

25. Bohr, D. F., D. C. Brodie, and D. H. Cheu. 1953. Effect of electrolytes on arterial muscle contraction. Circulation. 17: 746-749.

26. Haddy, J. F. 1960. Local effects of sodium, calcium and magnesium upon small and large blood vessels of the dog forelimb. Circ. Res. 8: 57-70.

27. Raizner, A. E., J. C. Costin, R. P. Croke, J. B. Bishop, T. V. Inglesby, and N. S. Skinner. 1973. Reflex, systemic and local hemodynamic alterations with experimental hyperosmolality. Am. J. Physiol. 224: 1327-1333.

28. Arvill, A., B. Johansson, and O. Jonsson. 1969. Effects of hyperosmolarity on the volume of vascular smooth muscle cells and the relation between cell volume and muscle activity. Acta Physiol. Scand. 75: 484-495.

29. Mellander, S., and J. Lundvall. 1971. Role of tissue hyperosmolality in exercise hyperemia. Circ. Res. 28: I39I45.

30. Gazitua, S., J. B. Scott, B. Swindall, and F. J. Haddy. 1971. Resistance responses to local changes in plasma osmolality in three vascular beds. Am. J. Physiol. 220: 384-391.

31. Hauge, A., and G. Bo. 1971. Blood hyperosmolality and 
pulmonary vascular resistance in the cat. Circ. Res. 28: 371-376.

32. Gazitua, S., J. B. Scott, C. C. Chou, and F. J. Haddy. 1969. Effect of osmolarity on canine renal vascular resistance. Am. J. Physiol. 217: 1216-1223.

33. Young, D. B., and H. H. Rostorfer. 1973. Blood flow and filtration rate responses to alterations in renal arterial osmolarity. Am. J. Physiol. 225: 1003-1008.

33. Betz, E., and M. Csornai. 1978. Action and interaction of perivascular $\mathrm{H}+, \mathrm{K}+$ and $\mathrm{Ca}++$ on pial arteries. Pfluegers Arch. Eur. J. Physiol. 374: 67-72.

34. Grun, G., U. Weder, R. Volkmann, and A. Fleckenstein. 1972. The mutual antagonism between $\mathrm{H}$ and $\mathrm{Ca}$ ions in the control of vascular tone and autoregulation: Neutralization of Ca-deficiency by experimental alkalosis Pfluegers Arch. Eur. J. Physiol. R9: 338-339.

35. Meiselman, H. J., E. W. Merrill, E. R. Gillilan, G. A. Pelletier, and E. W. Salzman. 1967. Influence of plasma osmolarity on the rheology of human blood. J. Appl. Physiol. 22: 772-781.

36. Schmid-Schonbein, H., R. E. Wells, and J. Goldstone 1973. Effect of ultrafiltration and plasma osmolality upon the flow properties of blood: A possible mechanism for control of blood flow in the renal medullary vasa recta. Pfluegers Arch. Eur. J. Physiol. 338: 93-114.

37. Gordon, D., F. S. Nashat, and C. S. Wilcox. 1981. An analysis of the regulation of sodium excretion during induced changes in plasma sodium concentration in anesthetized dogs. J. Physiol. 314: 531-545.

38. Baylis, C., W. M. Deen, B. D. Myers, and B. M. Brenner. 1976. Effects of some vasodilator drugs on transcapillary fluid exchange in renal cortex. Am. J. Physiol. 230: 11481158.

39. Ichikawa, I. 1982. Hemodynamic influence of altered distal salt delivery on glomerular microcirculation. Kidney Int. 22: S109-S113.

40. Schnermann, J., F. S. Wright, J. M. Davis, W. Stackelberg, and G. Grill. 1970. Regulation of superficial nephron filtration rate by tubulo-glomerular feedback. Pfluegers Arch. Eur. J. Physiol. 318: 147-175.
41. Wright, F. S., and A. E. G. Persson. 1974. Effect of changes in distal transepithelial potential difference on feedback control of filtration. Kidney Int. 6: $1114 a$.

42. Wright, F. S., and J. Schnermann. 1974. Interference with feedback control of glomerular filtration rate by furosemide, triflorin and cyanide. J. Clin. Invest. 53: 1695-1708.

43. Navar, L. G., P. D. Bell, C. E. Thomas, and D. W. Ploth. 1978. Influence of perfusate osmolality on stop-flow pressure feedback responses in the dog. Am. J. Physiol. 235: F352-F358

44. Schnermann, J., J. Briggs, and F. S. Wright. 1981. Feedback-mediated reduction of glomerular filtration rate during infusion of hypertonic saline. Kidney Int. 20: 462-468.

45. Dev, B., C. Drescher, and J. Schnermann. 1974. Resetting of tubuloglomerular feedback sensitivity by dietary salt intake. Pfluegers Arch. Eur. J. Physiol. 346: 263277.

46. Schnermann, J., N. Stowe, S. Yarimizu, M. Magnusson, and C. Tingwald. 1977. Feedback control of glomerular filtration rate in isolated, blood-perfused dog kidneys. Am. J. Physiol. 233: F217-F224.

47. Briggs, J. P., and F. S. Wright. 1979. Feedback control of glomerular filtration rate: Site of the effector mechanism. Am. J. Physiol. 236: F40-F47.

48. Levine, D. Z., and L. A. Nash. 1973. Effect of chronic acidosis on proximal tubular $\mathrm{H}_{2} \mathrm{O}$ and $\mathrm{HCO}_{3}$ reabsorption. Am. J. Physiol. 225: 380-384.

49. Nashat, F. S., J. W. Tappin, C. S. Wilcox. 1976. Plasma sodium concentration and sodium excretion in the anesthetized dog. J. Physiol. 254: 183-202.

50. Malnic, G., A. Mello-Aires, and F. Lacaz-Viera. 1970. Chloride excretion in nephrons of rat kidney during alterations of acid-base equilibrium. Am. J. Physiol. 218: 20-29.

51. Rector, D., and J. P. Clapp. 1962. Evidence for active chloride reabsorption in the distal tubule of the rat. $J$. Clin. Invest. 41: 101-108. 